\title{
Alive and well in Eastern Europe: A review
}

\author{
By Agnieszka Bron
}

Jindra Kulich, Grundtvig's Educational Ideas in Central and Eastern Europe and the Baltic States in the Twentieth Century, Copenhagen 2002, 209 pages, ISBN 87-87389-02-9. ${ }^{1}$

The Danish folk high schools and the educational ideas of N. F .S. Grundtvig are our common European heritage to adult education and especially to liberal adult education. Therefore, I believe, Jindra Kulich's recent contribution will be welcome and read with great interest as it gives us a detailed picture of liberal adult education in Central and Eastern Europe. With patience, care and a comparative approach, as well as in-depth knowledge of the topic, Kulich examines how the Danish ideas have influenced the past and the present of adult education provision. His study is based on a five months' field research in the region, as well as an analysis of the secondary sources. Kulich has a long-standing research interest in Danish folk high schools which, combined with a comparative knowledge of adult education in Europe and America and language skills (English, German, Danish, Czech and many Slavic languages) necessary for the task, makes him the most competent author to the issue under study.

The book gives us a comprehensive overview of not only Grundtvig's but also Kold's influence on adult education in the region. It takes into consideration such countries as Poland and Hungary, in which the influence was the strongest, as well as Estonia, Latvia, Lithuania, Romania and Russia plus seven other countries, where the influence was variable. Depending on the scope of sources as well as the idea's development in these countries, the author presents us with more or less detailed historical accounts and shows the present situation in these countries.

In the introduction, Kulich presents the study design, analysis of terminology and an outline of Grundtvig's and Kold's ideas. The issues, both theoretical and practical, of cultural diffusion, adoption and adaptation are also usefully stated. They are of theoretical and practical significance in the comparative research studies, or rather the outcome of such.

The second chapter deals with historical, political, economic and social backgrounds to the area under study. In chapter three, the accounts of the countries are presented. Kulich takes up a chronological approach, dealing with early awareness of or contact 
with the Danish idea, activities following its implementation before and between the two world wars, during communist rule and finally during independence after 1989. This last period should have given the folk high schools an opportunity for expansion especially within the context of civil society development. But, the reader might ask, has it really been possible? How much do the countries in the region look to Nordic ideas; or to what extent do they look back to their own liberal adult education tradition? Kulich cannot trace in his study a simple case of adaptation, even though an 'export' from Denmark and Sweden is quite apparent. He discusses hindrances to such 'export' and explains how the ideas of Grundtvig and Kold changed and modified in relation to different contexts and situations. The author concludes with a summary discussion of the material presented in the preceding chapters and addresses the problematical question of the future of the residential folk high school on the Danish model.

Two issues are relevant in this context. First, the promotion of liberal adult education, which is so very important for building up democracy and active citizenship especially in the countries under study. Second, the issue of opportunities and hindrances while exporting or importing educational ideas, models or institutions from one country to another.

Kulich's study is especially important at a time when adult education practice is going through changes directed towards vocationally-oriented courses. The state policy in many European countries focuses on education and training of adults which result in immediate rewards or profits, by preparing, qualifying and requalifying them for the labour market. This includes privatisation of the provision of adult education - also in the region under discussion, which is dominated by adult courses in foreign languages, computer skills and accounting. Since the labour market remains interested in qualifications, courses offering certification are the most common and predominate among educational provisions. Folk high schools as well as study circles in the Nordic countries are still supported by the states to keep their profile open to liberal education. Even though this kind of adult education has a crucial importance for participation in democracy, for civil society and citizenship, we face instead a reduction in a range of adult education practices throughout the rest of the European countries. This lack of balance between general and vocationally-oriented courses and institutions for adults, especially in new democracies, is very apparent and problematic. In other words, vocational and short-term courses, tailored for those who are out of the labour market, are provided at the expense of liberal education. 
Unfortunately, the result of Kulich's study points towards the lack of liberal adult education heritage in the new forms established in central and Eastern European countries. This may be seen in two ways: the content and the method of the new institutions are far away from the Danish model, and the main feature of the folk high school - its residential character is almost gone. This is not surprising taking into account the situation of the new democracies, where education in the form of credentials and diplomas as well as courses of short duration prevail.

Generally, behind the rhetoric of "lifelong learning", educational opportunities in the whole of Europe, are paradoxically narrowing the scope of adult education. Only the Nordic countries do not give up and remain strong, supported by the liberal state tradition of adult education. Should it be an ideal to look for and aspire to?

This is exactly what Kulich tries to explain by examining scrupulously the issue of 'export', which is placed in the last part of the book. First, he asks whether the institutions envisaged by Grundtvig and Kold were inevitably bound to evolve into the Danish style of folk high school as it is known today. From Kulich's investigation we can see that this was not necessarily so. What is more, the Nordic folk high schools can neither claim that they received such an inspiration nor that they were formed in the way Grundtvig and Kold had thought. Many folk high schools trace their roots to farmers' movements (like in Sweden) and, therefore, their shape becomes different. Grundtvig himself did not expect folk high schools to be exactly in the form he had once proposed. For Grundtvig a diversity of institutions was the key to 'folkeoplysning'. Kulich points out that even if the institutions claim self-acknowledged influence, it does not necessarily mean that they are copies of the Nordic model. By questioning the success of the cross-cultural borrowing, Kulich both directs our attention to the possibility of developing similar ideas and institutions and, at the same time, the difficulties of implementing the exact model in different social and cultural circumstances. Kulich follows Coolie Verner in writing that it is the idea and not the model that can be implemented and he points to the specificity of the region and especially its political, economic and social situation to explain why the folk high schools there do not any longer resemble the Danish model. There is, however, a great task to be accomplished by liberal adult education, i.e. to shape and develop civil society in the region. One lesson that can be learnt from the book is that similar tasks are needed in the Nordic countries as well. Even there social and political changes occur all the time, affecting especially a new generation. This 
triggers the need to adjust or change folk high schools together with the rest of liberal adult education.

Jindra Kulich's book is an important contribution to adult education, to research and practice. The book fills in the gap in our knowledge about Central and Eastern Europe which has not been easily accessible for the researchers and practitioners so far.

\section{Notes}

1 This review was first printed in International Journal for Lifelong Education, vol. 22, No. 5, 2003, pp. 547-548, website: www.tandf.co.uk/journals 